\title{
AN ERA OF DARKNESS: SATYAJIT RAY'S ANTICOLONIAL PROJECT
}

\author{
Binayak Roy \& Om Prakash Dwivedi \\ University of North Bengal \& Bennet University (India)
}

\begin{abstract}
Satyajit Ray's films are enriched with ideological concerns and engage with the issues of colonialism and the crisis of nationhood. His post 1970 films present an artist's anguished response to the betrayal of the Nehruvian dream and to the anachronism of his own cherished values. It was also in this period that Ray turned to India's colonial past and critiqued the dynamics of power relations. This essay studies how Shatranj ke Khilari (The Chess Players, 1980) assesses the reasons for colonization of India and its culture by the Britishers and how, in Ashani Sanket (Distant Thunder, 1973), he criticized the Raj, the mercenaries and the complexities in Indian society where he denounces the Bengal Famine of former times. Keywords: Empire, Orientalism, Feudalism, Bengal Famine.
\end{abstract}

UN TIEMPO DE OSCURIDAD:

EL PROYECTO ANTICOLONIAL DE SATYAJIT RAY

\section{RESUMEN}

Las películas de Satyajit Ray muestran su perfil ideológico e interpelan a las temáticas del colonialismo y la crisis de nacionalidad. Las películas que dirigió después de 1970 muestran la respuesta ansiosa que suponía la traición a los valores de Nehru y el anacronismo de los valores que Ray consideraba necesarios. En este período Ray también investigó el pasado colonial de India y denunció la dinámica de las relaciones de poder que existieron. Este ensayo estudia cómo Shatranj ke Khilari (Los jugadores de ajedrez, 1980) evalúa las razones culturales por las que India fue colonizada por Reino Unido y, en Ashani Sanket (Trueno distante, 1973), critica el Raj, los que cometieron crímenes despiadados y las complejidades de la sociedad india de la época, arremetiendo especialmente contra las condiciones que desencadenaros la Hambruna en Bengala.

Palabras Clave: imperio, orientalismo, sistema feudal, hambruna en Bengala.

DOI: https://doi.org/10.25145/j.recaesin.2021.83.04

Revista Canaria de Estudios Ingleses, 83; November 2021, pp. 51-65; ISSN: e-2530-8335 


\section{INTRODUCTION}

As India became increasingly crucial to British prosperity, millions of Indians died completely unnecessary deaths in famines [...] a result of what one can only call the British Colonial Holocaust. (Tharoor 176)

Satyajit Ray's films are almost invariably concerned with man's viable connection with his society, his world, his universe. They advocate not the self's mindless submission to contemporary society but a new alignment between them. His heritage might have contributed to this libertarian stance. Belonging to a family with strong links to the Bengal Renaissance, Ray inherited the worldview of a class deeply committed to the European Enlightenment philosophies of progress. Expected therefore is the progressive, secular, cosmopolitan, liberal-humanist ideal of his work. Ray made a novel attempt to define the modern as a special hybrid discourse by combining Western liberal ideas and traditional Eastern values. In Ashis Nandy's words, Ray "lived with a plurality of selves, and a part of him was as deeply Indian as a part of him was Western" (43). Ray's self-confessed credo is to present "not just single aspects of our life today, like contemporary politics, but a broader view of Indian history" (Roy 310). Hence his persistent efforts to describe the making of a nation as it emerges from its feudal and colonial past, and embraces modernity to become a new, hybrid postcolonial society. Amartya Sen rightly asserts that "Satyajit Ray insists on retaining the real cultural features of the society that that he portrays, his view of India [...] is full of recognition of a complex reality with immense heterogeneity at every level" (129). His India, remarks Judith Brown, was conceived as a "composite nation that included a great diversity of peoples and reflected a many-layered sense of 'being Indian' that grew out of the subcontinent's long history of dealing with outsiders" (28). Ray's idea of the modern in this context does not envisage a complete rupture with India's past but an evolution of the nation's present from its traditions, the dynamic interplay of the past and the present. Despite the partition of India in 1947, he retained his vision of a national identity born of diversity and sustained by tolerance and secularism.

Ray's initial enthusiasm for western modernity begins to evaporate as he faces up to an increasingly disillusioned post-independence India hostile to his Renaissance values of progressiveness, idealism and individual integrity. He perceives the canker of inexorable materialism eating into the foundations of long-cherished ethical values:

Looking around me I feel that the old values of personal integrity, loyalty, liberalism, rationalism, and fair play are all completely gone. People accept corruption as a way of life, as a method of getting along, as a necessary evil. (qtd Robinson 1989: 340).

Incisive is Ray's insight that consumerism begins by blunting sensibility and ends up by smothering conscience: "In acquiring material comforts you grow numb with placid acceptance. Maybe you resist in the beginning. But the internal and external pressures crowd to a point where you learn to overlook the moral decline they spell" (qtd Robinson 1989: 340). A brooding skepticism shrouds his 
post-1970 films that present a post-Nehruvian India plagued by unemployment and corruption. In his essay "Problems of a Bengali Film Maker" (1958), Ray spells out his ideological stance by asserting that the authentic Bengali/Indian filmmaker "must face the challenge of contemporary reality, examine the facts, probe them, sift them, and select from them the material to be transformed into the stuff of cinema" (qtd Cooper 5). He thus made a novel effort to negotiate between cinema and society, the symbolic and the material. Ashis Rajadhyaksha quite rightly argues that in the 1960s and 1970s, Ray shared with most Indian artists of his generation "the classic liberal nationalist discomfort [...] when the 'Naxalite' Communist Party of India (MarxistLeninist) appropriated for itself the whole voice of radical change" (qtd Cooper 6). Ray's middle- class protagonists, all victims of this dehumanizing rat-race, struggle to hold on to their liberal values. Aranyer Din Ratri (Days and Nights in the Forest, 1970) and the succeeding Calcutta trilogy (namely Pratidwandi, The Adversary, 1970; Seemabaddha, Company Limited, 1971; Jana-Aranya, The Middleman, 1975) highlight the disoriented middle-class youth, corrupt urban culture, bureaucratic bungling, and insidious neocolonialism. These films present an artist's anguished response to the betrayal of the Nehruvian dream ${ }^{1}$ and to the anachronism of his own cherished values.

It was also in this period that Ray turned to India's colonial past and critiqued the dynamics of power relations. Ray's first serious script, interestingly, was based on Rabindranath Tagore's Ghare Baire (The Home and the World) in 1946, a film he subsequently made in 1984 . He also wrote scripts based on two anticolonial short stories by writers committed to communism: Manik Bandyopadhyay's "Bilamson" ("Williamson") and Subodh Ghosh's "Fossil". These two short stories portrayed the nexus between the British colonialists and Indian feudalists. Subodh Ghosh's "Fossil" (1940) and "Bilamson" (1943) were allegories representing the establishment and perpetuation of British colonialism in India and anticipated Ray's major work Shatranj ke Khilari (1980). "The notion that the decadent representatives of feudal India sustained colonialism", contends Chandak Sengoopta, "was central to contemporary communist doctrine and propaganda" (8). Ray's films are hence not simply concerned with liberal humanist values, as it has been often alleged, but are enriched with ideological concerns and engage with the issues of colonialism and the crisis of nationhood.

${ }^{1}$ Nehru visualized a progressive, secular, pluralistic but tolerant, industrialized, democracy. India's modernity was reflected in its fusion of past and present and its assimilation of divergent traditions yet remaining a unified whole. 


\section{THE MARCH OF THE EMPIRE: SHATRANJ KE KHILADI (THE CHESS PLAYERS), 1980}

The regions of Bengal and Oudh hold high importance in the Indian history. Whereas the Bengal renaissance witnessed a revival of the socio-cultural and intellectual domains during the British raj, Oudh has its own share of popularity in the fields of arts, music, and Urdu poetry. These two regions are also abundantly important in context to the British colonialism in India. Sutanuti, one of the three villages, which were merged to form the present-day Kolkata, was also the first site which came into the East India Company's possession in 1690. (India Today 2018) Whereas Siraj-ud-Daula's defeat at the hands of Robert Clive in the Battle of Plassey (1757) opened way for the territorial expansion of the Company in India, Oudh was its last annexed territory in 1858 . As Reena Dube astutely observes, "these two historical sites mark the beginning and, in a sense, the culmination of the discourse of empire building" (14).

An understanding of these two culturally diverse regions is crucial for one to approach Satyajit Ray's The Chess Players (TCP) (1977). The movie's plot covers the Oudh region through which Ray weaves the colonial narrative of India. TCP is an adaptation of the great Hindi writer, Munshi Premchand's short story, Satranj Ke Khilari (The Chess Players, 1924). It can be added that Ray put at stake his glorious career by making a film in Hindi and going beyond the Bengal since this was his biggest budget film. Often critiqued for his strong Bengali affiliations and roots, this film reflects Ray as a national filmmaker, not limited to any particularistic region/ culture. Joan Mellen lauds Ray for his brave effort in coming up with "a HindiUrdu language that was not as familiar to him as the Bengali language, in tribute to a writer (Premchand) who was not part of the Bengali intelligentsia" (1978). The outcome of such a venture turned out to be a surprisingly successful "film that has remained pretty much unparalleled in the world of cinema, showing one of the most important chapters in imperial Britain's conquest of India through the eyes of Ray the detached historian" (2017).

Ray's creative imagination was certainly ahead of his times, and he used its power to make audience see the unseen, or the hidden yet stark realities of life; in the case of TCP, the British takeover and the colonial life in India. He offers a lens to look at and assess the reasons for colonization of India and its culture by the Britishers. His critique of the feudal system in India and the way it inflected, in fact, heightened and legitimized injustices over the subalterns, not to forget their own overindulgence in merry-making and all sorts of luxuries, make them completely oblivion of the lurking threat in the form of the Britishers. Perhaps, TCP could be seen as Ray's thoughtful attempt to drive home the point of national consciousness and its importance for decolonization. In Hind Swaraj (1909), Gandhi made a clarion call that "home rule [independence] must be grounded on the control that leaders and citizens exercise over themselves" (52). The abeyance of this self rule in TCP has obvious reasons. It would be wrong to approach the movie with the popularized view that the Oudh elites failed to protect the kingdom and their subjects due to their immersion in apolitical activities. However, a point can be made in context 
to the overall feudalist structure and their approach to the British colonial rule in India, which often gave the elites good returns in exchange of their submission to it. The element of individual responsibility to protect and safeguard his/her land, as advocated by Gandhi, finds no place in Ray's movie, which reinstates the resolute blindness and rationality of many feudalists during the British colonial period.

Ray gives an ironical start to the movie. The audience is introduced to Mirza Sajjad Ali and Mir Roshan Ali playing the game of chess and deeply engrossed over their next move in the game:

Look at the hands of the mighty generals deploying their troops on the battlefield. We do not know if these hands ever held real weapons. But this is not a real battle where blood is shed and the fate of empire decided. (00:00:24-00:00:43)

The close focus of the camera and the voice over on the hands are strategically important as they immediately render the centrality of battlefield in the movie. Hands symbolically stand for attack and defense mechanism in battlefield, and, the weaker ones, meet a tragic fate. Also, it needs to be added that hands, particularly those of the colonized ones also played increasingly vital role in shaping, strengthening, and proliferating the British empire across the world.

Similarly, the game of chess stands as a metaphor for the movie's plot. The unfolding of events with every move in the game (un)make characters and their destinies in context to the British rule in India. These characters also represent a marked tension between colonialism and nationalism, which get exhibited in the case of Wajid Ali Shah and General Outram on the one hand, and Meer and Mirza on the other. It is important to comment here on the structural narrative differences that is found in Ray's adaptation of Premchand's story "Satranj Ke Khilari” (1924). Whereas Premchand's story is delimited to the tussle between the native elites of Oudh region, Ray heightens the tension by adding the characters of Wajid and General Outram to the movie's plot. Reena Dube points out:

The metaphor of chess playing is central to the historical debate about Awadh. Premchand used the playing of chess by Comic Representations of Indigenous Enterprise the two nawabs to signify lack -the lack of indigenous enterprise and the absence of political engagement and patriotism. For Ray, chess is the perfect strategic vehicle to explore and debunk the British colonialist claim that the impulse for enterprise, innovation, and scientific experimentation belonged wholly to the West. (130-31)

Commenting on the use of the chess players in the movie, Ray defined it as a "political event shown in a documentary fashion and running parallel to a short story. In this context, Mellen argues that for Ray, such a plot said "was the only way the political story could credibly be told in a fiction film. You don't see the chess players in conjunction with the King or the British, but why must you?" (1978). It is for this reason it makes sense to approach the movie without any preconditioned notions.

The political outlook of the movie is enmeshed with the fate of Oudh's freedom from the British. The warning of the movie's narrator in the opening scene 
is indicative of a lurking threat ahead: "save your King, for if the King is lost, the battle is lost" (00:03:33-00:3:35). Undoubtedly, the movie's plot is charged with political contestations plaguing Oudh. It also reflects the culpability of the feudal class in failing to defend their kingdom from Britishers due to their immersion in games, arts and music, which ostensibly define the Oudhi culture. Unfortunately, this provided an alibi for the Britishers to intrude and finally annex the region. For example, the prologue to the movie has a scene in which we come across the British colonizer in Wajid's court. The voice over informs us of Wazid's obsession with his crown, which he had once sent to the Great Exhibition in London in 1851. Subsequently, a letter being written by Lord Dalhousie is being read out:

The wretch in Lucknow who has sent his crown to the Exhibition would have done his people and us a great service if he had sent his head in it -and he would never have missed it. That is a cherry which will drop into our mouths one day. $(0: 07: 24-00: 7: 41)$

The political and economic exchanges emerge out forcefully in the prologue scene in which Nawab Wajid is found asleep on the throne. Right next to him is a cake with Oudh's name inscribed on it. General Outram arrives and wakes up Wajib in an angry mood. To pacify his anger, Nawab Wajid cuts a piece of the Oudh cake and offers it to the General, who happily eats it and walks off. The narrator then concludes the prologue: "Poor Wajid! If only you knew what was in the mind of the Resident of Lucknow, General Outram."

The politically charged prologue renders a historical framework through which to analyze the movie and "to educate," the audience, to use Andrew Robinson's terms (221). In Robinson's framework, the seven-minute prologue becomes a medium through which "the (Indian as well as the Western) audience's widespread ignorance of the facts of the relationship between the British and Oudh in the century leading to the Annexation -in India as much as elsewhere" could be addressed (6). Darius Cooper views the events in the prologue as "mocking commentary" and "the lush visuals," which systematically "constitute a cultural attack on Oudh's elite itself and lay bare the hollowness of its elites and of their brand of native nationalism" (202). The movie maps the trajectory of the hollow nationalistic consciousness of elite Indians and provides an open space to relook at the historical dimension of the British colonialism in India. TCP is unique because it refuses to assign sole responsibility for the colonization to the colonizers. Commenting on the comparative lens rendered by the movie to examine the British colonialism, Joan Mellen argues that "the aristocrats, the King, the court ministers who have lined their pockets at the expense of the people -all share responsibility for the country's loss of independence" (1978).

The game of chess also triggered a loss of interest of Mirza in his wife. His wife Khurshid, therefore, calls it a "stupid game" (00:29:28), and reprimands her stating, "you only care for that game. You love that game more than you love me" (00:30:05). Reversely, Mirza tries his best to appease her by replying, "how can you say that? I left the game because you called" (00:30:15). In fact, he goes on to assign his interest in chess with a logic that ever since he started playing chess his "power 
of thinking has grown a hundredfold" (00:30:30). In one such scene, Khursid's aversion to the chess makes her hide the chess pieces. Meer and Mirza are led to believe that the pieces have been stolen by some thief and as the shops are closed Mirza decides to borrow the chess from his lawyer. Their search for the chess takes them to the lawyer only to find him in coma. Finding a chess in the ailing lawyer's room, they start playing it only to stop it soon due to the lawyer's sudden demise.

On their way back, they hear a drummer announcing the march of the British forces through Lucknow to Oudh. This hints at a possible annexation of Oudh soon, but the indifferent attitude of both the Nawabs puzzle and lend some humour to audience. Meer's rubbishes off the announcement of the drummer with a question "Mirza Sahib why do people spread rumors?" (00:54:01). At this point, the political life gets lost in the personal interests. In fact, Meer's immediate concern right now is to make use of the glorious day: "What a glorious day, yet we have to spend it in idleness" (00:54:20-00:54:24). Mirza replies, "Meer Sahib, for every problem there is a solution. One must know where to seek it" (00:54:28-00:54:32).

Reena Dube situates the theme of "idleness" within the cultural realm of Oudhi. She argues: "[W]ith this reversal chess becomes the realm of work, and the public-political events of Awadh become the realm of idleness" (154). The pervasive issue of idleness in the movie can be seen as a political satire, not only on the elite's sense of nationalism, which was surprisingly missing, but also on the overall sociocultural life of Oudh as found abundantly in the rich folklore. Abdul Halim Sharar sums up the Oudhi/Lucknowi culture with the famous proverbial joke of two friends waiting for a train on a railway platform (Sharar 194). Surprisingly, when the train arrives, they tell each other "After you. "No, after you" (194), and in this overt display of gentlemanly courtesy, the train departed, leaving them both on the platform. Sharar argues that this extreme display of good mannerism caused huge dent to the Nawabs and the Oudhi people, and, ultimately, resulted in its annexation by the British. Dube examines these problematics of the Oudhi elites and their concomitant failure to protect the kingdom, not totally located in their focus on the chess game, rather, in their openness, warmth and gentle mannerism. The fact remains that there was no place for gentlemanly behavior in the entire colonial enterprise. It was mostly a game of Othering with all the rules distorted and manipulated to favour only the Whites. The British Empire was notorious for decimating the trust of the colonized wherever they went. Their politics was based on rationality, which was diametrically opposed to the political outlook in India.

The use of rationality underpinned with deceit and misconstruing the truth reinforces Edward Said's theory of Orientalism to examine the hegemony that the West exercises over the East. Said, as we know, is singularly interested to show "how the will to examine Orientalism" and "how the will to exercise dominant control [has]discovered a way to clothe, disguise, rarefy, and wrap itself systematically in the language of truth, discipline, rationality, utilitarian value and knowledge" (216). Whereas Leela Gandhi sees "Orientalism as a discourse which invents or orientalizes the Orient for the purposes of imperial consumption" (88), Alexander Macfie argues that the creation of the Orient involves a process of the creation of a series of stereotypical images, according to which "Europe (the West, the 'self') is 
seen as being essentially rational, developed, humane, superior, virtuous, normal and masculine, while the Orient (the East, the 'other') is seen as being irrational, backward, despotic, inferior, depraved, aberrant and feminine sexually" (2002: 8). Seen in this context, the movie posits a perfect space to rethink colonialism as a game, which could only be countered, not through delicate mannerisms or goodness, rather with a strong focus on the ability to see through the moves/motifs of the British.

The failure of Awadh rulers to keep an eye on the changing pulse of the politics ostensibly resulted in their oppression and colonization. According to Dube, terms such as ' 'misrule' and 'maladministration' were used ad nauseam by colonial administrators to justify the Company's annexation of Awadh. Nationalist historiography and literature concurred with the British, with the important exception that the terms of nationalist critique were that Awadh lacked patriotism and a passion for politics" (96-97).

The last scene of the film explicitly brings out the element of betrayal. Meer cheats Mirza by positioning his piece in a favourable position, which ostensibly results in Mirza's loss, and a heated altercation between the two friends. This scene is equally suggestive of betrayal of relationship between the East India Company and India. The Company, which we all know, arrived in India for business operations ended up with a subsequent colonization of Indians. It is here that the character of Nandlal attains greater significance. Nandlal, a guest of the Nawab, is a Hindu teacher, and, also, happens to be the accountant for the British administrator, $\mathrm{Mr}$ Collins. It was Nandlal who taught Meer and Mirza the game of chess, with an added warning that "we may have invented the game, but it's the British who have taken it up." (00:19:08) The juxtaposition of this warning scene with the movie's last scene where Mirza picks up a chess piece and announces, "[m]ove over, Minister. Make way for Queen Victoria!" (01:53:02), points to the fact that rule of the game has changed and, that, in the game of power, friendship, loyalty and trust do not find any place.

This climax is also important for making us understand the projection of the Nawabs as effeminate characters. To see the movie only as a critique of feudalism or the elite Nationalists incapable of fighting against the Britishers would be a sweeping generalization since TCP subverts the historiography by leaving audience with powerful questions to think over. One can only dig out meanings if s/he engages with the plot thoughtfully. In fact, the scathing criticism that Ray continues to receive for the projection of the Nawabs in negative shade only lies in the inability or vested disinterest to understand Ray's motifs behind such a narrative. Likewise, Rajbans Khanna's critique of Ray is also symptomatic of such an imaginative failure. Responding to Khanna's critique of the movie to fabricate the nationalist history, Ray contends forcefully in his piece published in The Illustrated Weekly of India (31 Dec 1978):

One of the most famous Indian journalists of the period, Girish Chunder Ghose, wrote in his weekly, Hindu Patriot, a few days before the Annexation: 'If Oude is misgoverned, if the King of Oude is a voluptuary and a puppet, if the Minister is a harpy, if the zamindars of Oude are graceless malcontents, we ask, where are the 
proofs of this lamentable state of things? If a tithe of what is written and said about Oude and its government were true of that country and its governors, then society should not have existed there for a day... and a revolution more terrible than the French Revolution would have, despite the presence of the British troops, marked the progress of events in that country. (1978)

Ray accepts that his attempt in the movie is to juxtapose a story about "two chess playing jagirdars in Wajid's Lucknow, with the historical event of the Annexation where the protagonists are Wajid and Outram" (1978).

\section{INGLORIOUS EMPIRE: ASHANI SANKET (DISTANT THUNDER, 1973)}

Ray himself remarked that, in Shatranj (1980) he was "portraying two negative forces, feudalism and colonialism. You had to condemn both Wajid and Dalhousie. This was the challenge. I wanted to make this condemnation interesting by bringing in certain plus points of both the sides. You have to read this film between the lines" (qtd Robinson, "Introduction," 1989: 12). While he has been accused of being soft towards British colonialism in Shatranj, Ray is unscathing in his critique of the Raj, the mercenaries and the complexities in Indian society in Ashani Sanket (1973). Ashani Sanket is Ray's cinematic adaptation of Bibhutibhushan Bandyopadhyay's tragic tale of the man-made Bengal famine of 1943, a seemingly forgotten Holocaust, ostensibly a result of Britain's war with Japan. Ray thus screens India in the different phases of her subjection right from 1856 to 1943. Bengal, unlike other provinces of India, had to undergo a traumatic period in the 1940s, during the World War II. The British callously disregarded and even facilitated the starvation deaths of 3-5 million people in rural Bengal. While ironically India was very significantly supporting the British war effort with over 3 million troops (after again being denied independence after its WWI support), Winston Churchill exported food from India that was desperately needed domestically, and even barred other countries who were ready to send aid to India from doing so. This after a series of famines under the British Raj, such as one in 1770 that decimated $1 / 3$ of Bengal's population (10 million people) and that was intensified by the greed of the East India Company.

Amartya Sen has demonstrated quite convincingly in Poverty and Famines that the deaths in the 1943 famine were caused by British policies and not by any drastic slump in food production. While the famine killed millions, with agricultural labourers forming by far the largest group of those killed", asserts Sen, "Bengal was producing the largest rice crop in history in 1943 (77-78). The war disrupted the economic system of Bengal and Burma in many ways, including its concentration of a privileged workforce in Calcutta and other cities. The network of supply and demand collapsed under the impetus of the profit motive. Free enterprise, in the form of speculation unchecked by a corrupt state government divided against itself and an indifferent British Raj, was the main cause of the Famine. Paul Greenough 
explains that " $[\mathrm{r}]$ ice which ordinarily flowed in non-commercial exchanges between cultivators and their dependents [and] began to veer into the commercial channel, and a much larger proportion than usual of the stored rice supply fell into the hands of outsiders" (212). There was speculation on all sides ranging from the humblest cultivator to the richest Marwari merchant in Calcutta fattening himself on every kind of business generated by war.

Human greed for money cruelly dissolved the web of unenforceable obligations binding landlord to peasant, essentially feudal in nature, leaving the peasants starved. Madhusree Mukherjee sums up the grim situation in Bengal quite adroitly:

By the spring of 1943 almost all the machine-milled rice seems to have ended up with the government and its agents, as well as some part of the hand-milled rice. A district official would subsequently tell the commission investigating the famine that even the larger landowners had very little rice left early that year: "Whatever stock was available had been bought up at fantastic prices by military contractors and speculators. (96)

London ate India's bread while India starved, and in 1943 nearly four million Bengalis died. It was their own fault, according to the odious Churchill, for "breeding like rabbits" (Limaye 1). Collectively, these famines amounted to a British colonial holocaust. Greenough has compared its impact on Bengal to that of the Depression on the industrialized world in his book Prosperity and Misery in Modern Bengal. Its roots went deep into Bengali society. With a rising population and declining production Bengal was no longer self-sufficient in rice and depended upon imported rice from Burma. With the fall of Burma in March 1942, all imports stopped abruptly. Rice-traders and speculators were alert to the meaning of food shortages in Chittagong and Midnapur, and wholesale grain prices continued to rise. The Bengal ministers played down scarcity and minimized the reasons responsible for high prices, hoping to avoid blame as well as public panic. Price controls had been delayed and then failed because the Bengal government had no buffer stocks to influence market prices.

Ashani Sanket is set in a poor rural Bengali village where most people are illiterate and even unaware of the war going on in the other side of the world. In the beautiful opening scene Ananga and her friend Chutki are fascinated by the flying jets which hardly mean anything more to them than a distant thunder. They are not even aware that those jets are flying to war. Ananga and her husband Gangacharan are the newer inhabitants of the village and belong to the respectable Brahmin class. A pseudo-scholar, Gangacharan is to the ignorant villagers a priest, doctor and teacher rolled into one. The villagers literally worship him, and provide him food, clothes and other day-to-day necessities as tokens of gratitude. He confidently asserts to the villagers that "[o]ur king is fighting the Japanese and the Germans" (00:32:2200:33:25). He has heard that a place called Singapore has fallen to the Japanese and, unaware of its geographical location, enlightens the villagers that Singapore is located somewhere in the other part of Bengal. The first glimpse of impending 
doom is seen in the form of a wizened old Brahmin gentleman who walks in from the neighboring village with news of a scarcity of rice, seeking a hearty meal for himself in turn (00:30:07-00:32:20). The crisis spreads like wildfire, and the village grocer announces that he does not have a supply of rice. Prices of all other food items soar in no time and soon they become unaffordable. Gradually the innocence of the village begins to crumble before Gangacharan and Ananga's eyes. The men worry at first, and then stoop to looting and rioting. The women are forced to hunt for snails from the pond and eat them, or to walk miles into a dense forest to dig up wild potatoes. Hoarders try to take advantage of the hunger of the poor villagers; some women are forced to sell more than their souls to lusting men in return for a meal. Gangacharan now realizes that people's reverence takes a backseat in the face of insatiable hunger, and that he himself has been reduced to a commoner, hunting for a fistful of rice.

Starvation engulfs the village and gradually strips the villagers off their humanity. There is a riot over rice at the local market; Biswas, the wealthiest man in the village lives amidst constant threats from the robbers. Chutki gives herself over to the scar-faced man at the local kiln for a bag of rice and flees with him to the city for food. The first boon Goopy and Bagha ask from the King of the ghosts in Goopy Gyne Bagha Byne (1969) is food. The clapping of their hands immediately dished out to them the meal that they desired. In Ashani Sanket, food was becoming scarcer as the price skyrocketed far beyond what was affordable and, in the end, there just was not any left. The film presents grim vignettes of the hands of the starved men and women praying for rice while their agonies rent the air. These events also bring about a more positive change in Gangacharan and Ananga. Gangacharan, who was arrogant and pompous, learns that he had lived his affluent life at the cost of the villagers. He becomes aware of the sacrifices others have made for him and that in this tragic ordeal there are no inequalities. Suffering and starvation erase all class and caste distinctions. The horrific turn of events arouses in them social responsibility.

Ray presents the horrors of death by starvation through an untouchable girl, Moti. A resident of Gangacharan's previous village she arrived as a welcome visitor to their house earlier as one whom they must not physically touch, by mutual consent. At the end she drags herself back to them for help, her eyes glazed for lack of food, and collapses under a tree. When Ananga offers her food in the shape of arum root, which is all that she has, the girl is unwilling to touch either it or the hand that brings it. She manages to raise her own hand feebly with four extended fingers to show she has not eaten for four days. The taboo of untouchability remains implanted in her psyche even at the point of death. As a death wish she feebly requests fish curry, a symbol of Bengali prosperity, which she could hardly have afforded even in times of plenty. Moti's plight compels Ananga to touch her; Gangacharan too abandons taboos and readily picks up the girl's hand to identify her pulse, but she already lay dead. Breaking yet another taboo, Gangacharan gives the corpse a proper cremation rather than leave it for the jackals to consume (01:27:40-01:34:54). In the context, this action is heroic; but this is heroism on the brink of extinction. Gangacharan thus finds his place in the lineage of Ray's protagonists whose integrity remains unshakeable and conscience infallible. 
The final unforgettable shot, where the sheer scale of the holocaust is brought home to the audience, sends a shiver down the spine even on repeated viewings (01:35:12-01:35:50). The silhouettes of Bhattacharji and his family can be seen approaching, returning to their house, trailing a family of dependants. Amidst this situation, Ananga announces her pregnancy. Gangacharan's radiance gives way to consternation as he looks on the approaching people in the distance and the impending doom that awaits them. The camera turns to the silhouettes of dozens and then hundreds of starving people (01:36:10-01:36:30). The title card displays that 5 million died of starvation because of this man-made famine of 1943 (01:36:4801:37:00). Ashani Sanket is a portrayal of the horrors inflicted on rural Bengal by the wartime famine, and of Gangacharan's new questioning of caste restrictions and privileges. The village is shown as a happy place before the onslaught of the crisis, but as soon as the famine arrives, people begin to lose all sense of proportions. It is this realization -that such a sudden, radical and unthinkable decline of human values can actually happen in the face of decimation- that truly sets Ashani Sanket apart as an understanding of the great famine of Bengal, and of the vulnerability of the human spirit.

\section{CONCLUSION}

Ray's cinematic representation of Indian history begins with Shatranj ke Khiladi (The Chess Pleyers) in which feudalism is pitted against colonialism as the British seek to annex the northern Indian province of Oudh in 1856 . He deliberately chose an event of the distant past and used all his cinematic strategies to invoke the pastness of the past. As major players, Nawab Wajid Ali Shah and General Outram might see themselves as the makers of history. But they are also chess pieces moved by the economic expansion of the East India Company and the larger dictates of Queen Victoria. The landlords Meer and Mirza are blind to historical change and represent the sophisticated decadence of the land-owning class of Lucknow. Jalsaghar (The Music Room, 1958) is akin to Shatranj ke Khiladi as it too presents, quite elegiacally, the passage from the old to the new. The old feudal order is replaced by the merchant middle class. The feudal landlord Biswambhar Roy is aware like Nawab Wajid that he represents a fading culture and cannot withstand the historical forces of change.

If Shatranj ke Khiladi presents the East-West confrontation, Charulata (1964) presents fusion. Set in 1879, India is now a part of the British Empire. Culture as an independent, purist entity is no longer tenable. Old authenticities, stabilities, and certainties collapse; hybridity based on assimilation and interlocking takes over. Ghare Baire (The Home and the World, 1984) is a perfect presentation of an inter-communal discord interweaved with cross-cultural interactions. Uncontrollable native agitation and the practice of Swadeshi and boycott represent a challenge to the racist British government. Ashani Sanket (Distant Thunder, 1973) delineates the mass starvation in Bengal in 1943 as a result of Britain's war with Japan. Starvation and famine affect everybody irrespective of his/her position in the caste hierarchy. India, on Ray's canvas, thus travels a long way from 1856 to 
1943, from colonization to pre- Independence. Ray's "history films are attempts", observes Ben Nyce, "to remind his Bengali audiences of the glories of the Bengali past; their goal is to establish a sense of national identity in the face of the enormous influence of the West" (4-5).

Ray's consistent anti-colonial stance never interfered with his cultural cosmopolitanism or his readiness to criticize various aspects of indigenous life and culture. Tagore and Ray, the two most iconic figures of cultural syncretism and humanism, were always eager to embrace useful or valuable aspects of Western culture but were "critically open" and opposed the "serious asymmetry of power" involved in colonial rule (Sen 119, 124). "The sharpest revelations of the truth in cinema", believed Ray, "come from the details perceived through the eyes of artists" (Ray, Deep Focus 2011: 38). The "sensitive artist's subjective approach to reality" was of prime importance to him, and this was true "as much of documentaries as of fiction films" (2011: 38). While British writers were primarily interested in the "more exotic and sinister aspects of India in what were basically stories of mystery and adventure" (2011: 73), barring Kipling to some extent, none could unravel the "vast, too complex, too multilayered" (2011: 73) realities of India: "The upshot was that, the effort of memoirists, Indologists and historians notwithstanding, India remained a nebulous entity to the West; a vast amorphism that refused to take on a semblance of the familiar" (2011: 76). It was Ray's endeavor to explore the myriad densities and complexities of India to the world, the ascendancy of the colonizers and the multiple forms of annexation and exploitation, the thousands of disparities in behavior, habits, rituals, dress, topography, language, etc. underlying the broad cultural pattern that is India. At the same time, he acknowledged the inscrutability of the subcontinent, asserting that a "true understanding (of India) will take time" for "cows are still holy here, and God is still a phallus" (2011: 91).

Review sent to author: $01 / 06 / 2021$

Revised version accepted for publication 07/06/2021 


\section{WORKS CITED}

Ashani Sanket (Distant Thunder). Dir. Satyajit Ray. ANGEL DVD. Catalog No: AVDVD120CE. (Last accessed 7 July 2021), 1973.

Brown, Judith. “The Jewel without the Crown.” Bloomsbury Review (15 Feb 1998).

Cooper, Darius. The Cinema of Satyajit Ray: Between Tradition and Modernity. Cambridge University Press, 2000.

Dube, Reena. Satyajit Ray's The Chess Players and Postcolonial Theory: Culture, Labour and the Value of Alterity. Palgrave Macmillan, 2005.

Gandhi, Leela. Postcolonial Theory: A Critical Introduction. Columbia University, 1998.

Gandhi, Mohandas K. Hind Swaraj. Navjivan Press, 1938.

India Today. "When Kolkata began as Calcutta: The history of the first capital of British India." (24 August 2018) online. https://www.indiatoday.in/education-today/gk-currentaffairs/story/when-kolkata-began-as-calcutta-the-history-of-the-first-capital-of-britishindia-1322194-2018-08-24.

Mellen, Joan. "Satyajit Ray Treats History as a Multilevel Chess Game.” (4 June 1978) online. https://www.nytimes.com/1978/06/04/archives/satyajit-ray-treats-history-as-a-multilevelchess-game.html.

Greenough, Paul R. "Indian Famines and Peasant Victims: The Case of Bengal in 1943-1944." Modern Asian Studies 14/2 (April 1980): 205-235.

LimaYe, Yogita. "Churchill's legacy leaves Indians questioning his hero status.” https://www.bbc. com/news/world-asia-india (21 July 2020).

Macfie, Alexander Lyon. Orientalism. Longman, 2002.

Muknerjee, Madhusree. The British Empire and the Ravaging of India during World War II. Basic Books, 2010.

Nandy, Ashis. "How 'Indian' is Ray?” Cinemaya 20 (1993).

NyCE, Ben. Satyajit Ray: A Study of His Films. Praeger, 1988.

Ray, Satyajit. Deep Focus: Reflections on Cinema. Ed. Sandip Ray. Harper Collins, 2011.

Ray, Satyajit. "My Wajid Ali is Not 'Effete and Effeminate'! Satyajit Ray.” (31 Dec 1978) Online. https://oudh.tripod.com/was/wasray.htm. (Last accessed 08 July 2021).

Robinson, Andrew. "Introduction." Satyajit Ray, The Chess Players and Other Screenplays. Faber and Faber, 1989.

Robinson, Andrew. “Satyajit Ray: The Inner Eye." University of California Press, 1989.

Roy, Karuna Shankar. “The Artist in Politics: An Interview with Satyajit Ray.” Drama Review 15/2 (1971): np.

SAID, Edward. The World, The Text, and The Critic. Faber and Faber, 1984.

SAID, Edward. "A Window on the world." The Guardian (1 August 2003). https://www.theguardian. com/books/2003/aug/02/alqaida.highereducation.

Satranj Ke Khilari (The Chess Players). Satyajit Ray, 1977. https://www.dailymotion.com/video/ x4fzqwi. (Last accessed 8 July 2021). 
Sengoopta, Chandak. “The fruits of independence': Satyajit Ray, Indian nationhood and the spectre of empire." South Asian History and Culture 2/3 (2011): 374-396.

SEN, Amartya. Poverty and Famines: An Essay on Entitlement and Deprivation. Clarendon Pres, 1981.

SEN, Amartya. The Argumentative Indian: Writings on Indian History, Culture and Identity. Penguin Books, 2005.

Sharar, Abdul Halim. “'Mashriqi Tamaddum ka Akhiri Namunah.' Dil Gudaz (1887-1926).” Lucknow: The Last Phase of an Oriental Culture. Trans. \& Ed. E.S. Harcourt \& Fakhir Hussain. Westview Press, 1976. 
